\title{
IMPACT OF FLOATING FEED ON GROWTH PERFORMANCE, YIELD AND SURVIVAL OF ROHU (LABEO ROHITA) AND TILAPIA (OREOCHROMIS NILOTICUS) IN TANK BASED INTENSIVE AQUACULTURE SYSTEM
}

\author{
Md. Hashibur Rahman ${ }^{1^{*}}$ and Md. Arifuzzaman ${ }^{2}$ \\ ${ }^{1}$ Bangladesh Fisheries Research Institute, Headquarters, Mymensingh \\ ${ }^{2}$ Department of Aquaculture, Bangladesh Agricultural University, Mymensingh \\ *Corresponding author: hasibkhan94bfri@gmail.com
}

Article Info:

Research Article

Received

01.09.2021

Reviewed

15.09.2021

Accepted

25.09.2021

\begin{abstract}
The present study was aimed to evaluate the growth performance and subsequent survival rate of the rohu (Labeo rohita) and tilapia (Oreochromis niloticus). The experiment was conducted in six concrete tanks under an outdoor laboratory shed from $10^{\text {th }}$ May to $29^{\text {th }}$ July, 2019. There were three replications for each treatment and feed was supplied at the rate of $12 \%, 8 \%$, and $4 \%$ of the body weight of rohu and $20 \%, 15 \%$, and $10 \%$ of the body weight of tilapia in $1^{\text {st }}, 2^{\text {nd }}$ and $3^{\text {rd }}$ month for rohu $\left(\mathrm{T}_{1}\right)$ and tilapia $\left(\mathrm{T}_{2}\right)$ respectively to assess the comparative growth performance. The initial weight of individual tilapia was $7.52 \pm 1.81 \mathrm{~g}$ and $14.75 \pm 0.19 \mathrm{~g}$ for $\mathrm{T}_{1}$ and $\mathrm{T}_{2}$, respectively. The final mean weight of each fish was 44.01 $\pm 5.65 \mathrm{~g}$ for $\mathrm{T}_{1}$ and $139.94 \pm 1.29 \mathrm{~g}$ for $\mathrm{T}_{2}$. The weight gains of fish were $36.49 \pm 4.09 \mathrm{~g}$ and $125.19 \pm 1.29 \mathrm{~g}$ for $\mathrm{T}_{1}$ and $\mathrm{T}_{2}$, respectively. The mean percent weight gain of tilapia was higher in $\mathrm{T}_{2}(1715.05 \pm 0.00)$ than $\mathrm{T}_{1}(485.23 \pm 0.00)$. Feed conversion ratio (FCR) in $\mathrm{T}_{1}$ and $\mathrm{T}_{2}$ were $2.86 \pm 0.14$ and $2.23 \pm 0.18$, respectively. Higher total production was obtained in $\mathrm{T}_{2}(1119.52$ g) than $\mathrm{T}_{1}(278.19 \mathrm{~g})$ with $100 \%$ survival in both the treatments. The water quality parameters for both of the species were within the suitable range. The study reveals that growth performance was higher in $\mathrm{T}_{2}$ than $\mathrm{T}_{1}$ having $100 \%$ survival rate in the concrete tanks.
\end{abstract}

Keywords: Floating feed, FCR, Growth performance, Intensive aquaculture, Yield.

\section{INTRODUCTION}

Fish is the second most important agricultural products in Bangladesh and today aquaculture is considered as one of the most promising resources of animal proteins and contributing a significant role in foreign exchange earnings, nutrition supply and contributing in our national economy as well. Among various segments of the fisheries subsector, the inland aquaculture has generally experienced the fastest growth, with the establishment of latest technologies, species, and intensification and improvement of farming, particularly in pond and tank-based aquaculture, entirely over the country. The contribution of fisheries sector in $2019-20$ was $3.50 \%$ to the total GDP of the country and approximately $25.72 \%$ to agricultural GDP (DoF, 2020). Now-a-days, fish production shifting to aquaculture as inland fisheries production has escalated over the years, but the productivity per hectare water area is not yet attained at its optimum (DoF, 2020). Aquaculture is the fastest growing animal-based food producing sector particularly in developing countries like Bangladesh and its production 
contributes to the livelihoods, employment and also meet the demand in terms of protein supply, food security and income generation of the increasing number of people throughout the world.

To fulfill the animal protein demand for growing population in Bangladesh intensive fish culture system may be an alternative to enhance fish production since fish contributes about $60 \%$ of animal protein to our daily food (DoF, 2020). The competition between aquaculture and other agricultural sectors is increasing in the context of land and water use. Therefore, to replenish the existing gap intensive aquaculture is growing to ameliorate the national fish production in the context of immense growth of population and declining land resource. In Bangladesh, conventional semi-intensive aquaculture system is generally followed in case of fish culture besides extensive system. However, with the increasing population, land area is declining in Bangladesh hence adoption of new farming technology in the plain land is need of the hour (Islam et al., 2020). Moreover, fish production per unit area much higher in intensive aquaculture system compared to semi-intensive and extensive system. Aquaculture ponds are often integrated into conservation and management systems while tank culture is often an efficient way of overcoming the matter of water shortages.

In this experiment, the stocking density for both of the species was adjusted to intensive (320 fish/decimal) system to achieve the expected result more accurately. To assess the amount of feed required in percentage increase of size and weight at a particular growth stage in relation to time (SGR) is very important. The initial and final weight data over time remain unaccustomed to calculate the growth performance. Therefore, the result is not accurate enough to understand the growth of fish in the intermediary stages of a production cycle (Lugert et al., 2016). Therefore, due to lack of the appropriate modeling to evaluate the growth of fish at different stage in relation to water quality parameter in intensive farming, this study is likely to be effective to develop a relationship between water quality parameters i.e., DO (dissolved oxygen), temperature, $\mathrm{pH}$, ammonia, nitrate, other dissolved gases and organic metals having direct effect on growth, maintenance and survival of fish.
The present study has taken rohu and tilapia as experimental species to explore the growth of fish in intensive culture system in concrete tanks by using floating feed. The intensive aquaculture increases the production of fish rearing exotic species. Intensive aquaculture of indigenous species can enhance the indigenous fish production in a particular/limited time. The aquaculture development and increase in per unit volume of water depends after all artificial feed (Shaheen et al., 2000). Fishes are rich in nutrients and among cyprinids, rohu (Labeo rohita) is the most popular fish species which is cultivated in Indian subcontinent (Ashok, 2020, 2021; Kumar et al., 2020). Rohu is considered as the delicious and prestigious fish species among other Indian major carps for its uniqueness and attributes (FAO, 2000). Tilapia (Oreochromis niloticus) regarded as an honest converter of organic matter into top quality which will survive in shallow and turbid water conditions (Stickney et al., 1979). Tilapia is very resilient species which may reduce the gap of accelerating worldwide demand for its protein sources and market demand (Romano and Ng, 2013). The use of commercial feed has become a time demanded initiative for the success of cyprinid and tilapia culture under intensive culture conditions particularly rohu along with other carps (Abid and Ahmed, 2009) and tilapia monosex culture. Chakraborty et al. (2020) and Chakraborty (2021) conducted research on rearing, spawning and nursing of Pangas in Bangladesh.

The study was conducted to specify the comparative growth performance, yield and FCR to optimize feed supplementation during the culture period and to make a rational decision for get better outcomes from tank-based intensive aquaculture system with the economic affordability of fish farmers. The study was carried out to assess the growth and production of rohu and tilapia focusing on different intermediate sampling stages to have better understanding on growth trends.

\section{MATERIALS AND METHOD}

\section{Experimental site}

Concrete made squared shaped tanks under a properly constructed shed were established in 
the backyard (south of the wet laboratory complex) of the Faculty of Fisheries, Bangladesh Agricultural University (BAU), Mymensingh. Water supply and exchange facility was also satisfactory there. Each tank is of $1 \mathrm{~m}$ length, $1 \mathrm{~m}$ width and $1.2 \mathrm{~m}$ depth and water volume in each tank was $1 \times 1 \times 1=1 \mathrm{~m}^{3}$. Among the six tanks, three tanks were used to study the growth, yield and survival of rohu (Labeo rohita) and remaining three tanks used to observe the consecutive growth performance of tilapia (O. niloticus) in intensive rearing system. Both the fish species were fed with floating to have better understating on various sampling stages.
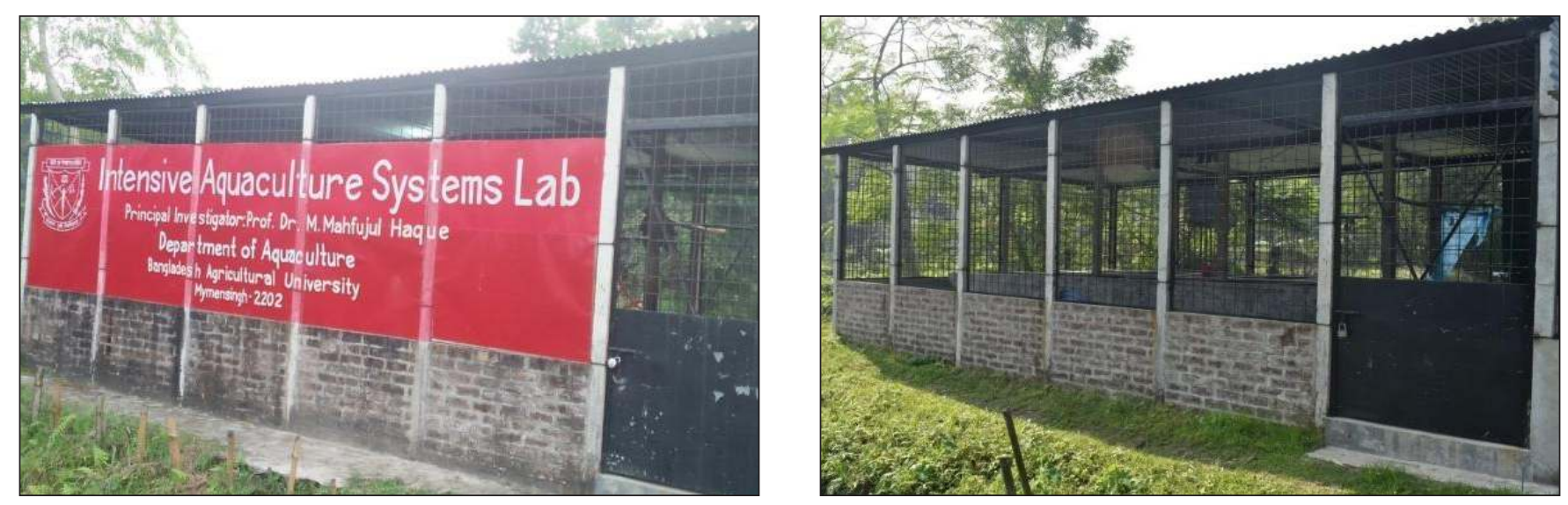

Fig.1: Intensive Aquaculture System Lab, BAU, Mymensingh.

\section{Experimental tanks}

For conducting the experiment, six concrete tanks were used. The bottom of the tank was made smooth and coated with white cement to make the bottom visible and facilitate the cleaning process easily. The outlet pipes of the tanks were closed to prevent water leakage. Siphoning process was followed to clean the tanks. Water was supplied from a deep tube well located near the experiment site.

\section{Experimental design and layout}

Rohu (Labeo rohita) and Monosex male tilapia $(O$. niloticus) fry was used as experimental species. For the experiment, two treatments were designed namely $\mathrm{T}_{1}$ and $\mathrm{T}_{2}$ and there were three replications for each. For both of the species, fry was released at the rate of 8 fry per tank that equivalent to the stocking density of 320 fish per decimal or about 80,000 per hectare with different average initial weight for six tanks individually.

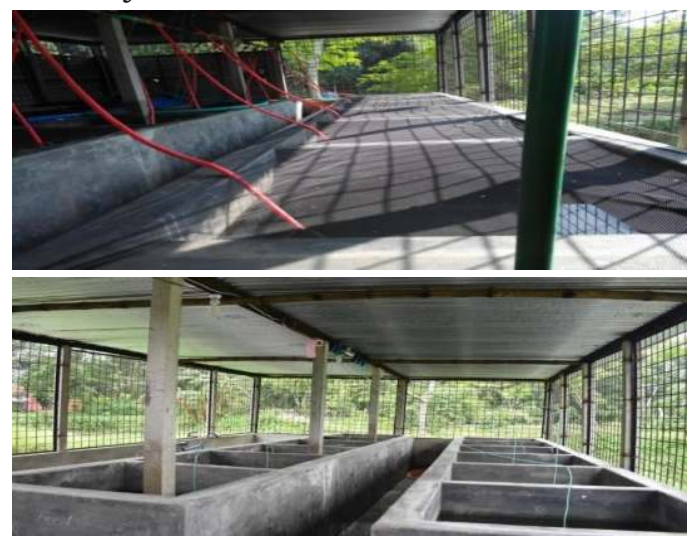

Fig. 2: Experimental concrete made tank.

Table 1: Design and layout of the experimental tank.

\begin{tabular}{|l|c|c|l|c|c|}
\hline \multicolumn{5}{|c|}{ Intensive Culture Unit } \\
\hline Replication & $\begin{array}{c}\text { Stocking density } \\
\text { (fry/tank) }\end{array}$ & $\begin{array}{c}\text { Average initial } \\
\text { weight (g) }\end{array}$ & Replication & $\begin{array}{c}\text { Stocking density } \\
\text { (fry/tank) }\end{array}$ & $\begin{array}{c}\text { Average initial } \\
\text { weight (g) }\end{array}$ \\
\hline $\mathrm{R}_{1}\left(\mathrm{tn}_{1}\right)$ & & 6.52 & $\mathrm{R}_{1}\left(\mathrm{tn}_{5}\right)$ & & 15.92 \\
\hline $\mathrm{R}_{2}\left(\mathrm{tn}_{2}\right)$ & 8 & 9.62 & $\mathrm{R}_{2}\left(\mathrm{tn}_{5}\right)$ & 8 & 14.61 \\
\hline $\mathrm{R}_{3}\left(\mathrm{tn}_{3}\right)$ & & 6.42 & $\mathrm{R}_{3}\left(\mathrm{tn}_{6}\right)$ & & 13.72 \\
\hline
\end{tabular}


Table 2: Experimental layout with six tanks.

\begin{tabular}{|c|c|}
\hline Treatment 1 & Treatment 2 \\
\hline $\begin{array}{c}\mathrm{T}_{1} \mathrm{R}_{1} \\
\text { (Tank No. 1) }\end{array}$ & $\begin{array}{c}\mathrm{T}_{2} \mathrm{R}_{1} \\
\text { (Tank No. 4) }\end{array}$ \\
\hline $\begin{array}{c}\mathrm{T}_{1} \mathrm{R}_{2} \\
\text { (Tank No. 2) }\end{array}$ & $\begin{array}{c}\mathrm{T}_{2} \mathrm{R}_{2} \\
\text { (Tank No. 5) }\end{array}$ \\
\hline $\begin{array}{c}\mathrm{T}_{1} \mathrm{R}_{3} \\
\text { (Tank No. 3) }\end{array}$ & $\begin{array}{c}\mathrm{T}_{2} \mathrm{R}_{3} \\
\text { (Tank No. 6) }\end{array}$ \\
\hline
\end{tabular}

\section{Selection of feed and feeding frequency}

The fishes were fed commercial floating feed named as 'Mega Feed' and 'Quality Feed' for $\mathrm{T}_{1}$ and $\mathrm{T}_{2}$, respectively. In first 30 days of the experiment, the size of floating feed used for feeding the fish was $0.25 \mathrm{~mm}$. Then the pellets of $0.5 \mathrm{~mm}$ were used to feed the fish during the rest experimental period. During experiment, feed was given at the rate of $20 \%, 15 \%$, and $10 \%$ of the body weight in $1^{\text {st }}, 2^{\text {nd }}$ and $3^{\text {rd }}$ month, respectively.

Table 3: Proximate composition of floating feed as per labeling on the feed bag.

\begin{tabular}{|l|c|c|}
\hline Proximate composition & $\begin{array}{c}\mathbf{T}_{1} \\
\text { Floating feed (\%) }\end{array}$ & $\begin{array}{c}\mathbf{T}_{2} \\
\text { Floating feed (\%) }\end{array}$ \\
\hline Moisture & 12 & 10 \\
\hline Protein & 32 & 28 \\
\hline Fat & 5 & 6 \\
\hline Starch & 27 & 22 \\
\hline Fiber & 9 & 3 \\
\hline Ash & 12 & 12 \\
\hline Calcium & 2 & 2 \\
\hline Phosphorus & 1 & 1 \\
\hline
\end{tabular}

\section{Feeding strategy}

The daily ration of fish was adjusted with the body weight. The total amount of ration was divided into two parts and half was supplied to the fish in the morning $(9: 30 \mathrm{am})$ and the remaining half was delivered in the afternoon $(4: 30 \mathrm{pm})$. During experimental period, there were three replications for each treatment and feed was supplied at the rate of $12 \%, 8 \%$, and $4 \%$ and $20 \%, 15 \%$, and $10 \%$ of the body weight in $1^{\text {st }}$, $2^{\text {nd }}$ and $3^{\text {rd }}$ month for $\mathrm{T}_{1}$ and $\mathrm{T}_{2}$, respectively. The daily ration was calculated as the following rate in the Table- 4 .

Table 4: Feeding chart for the experimental fish.

\begin{tabular}{|l|cc|}
\hline Days & Amount of feed (\% of the total body weight of fish) \\
\hline & $\mathbf{T}_{1}$ & $\mathbf{T}_{2}$ \\
\hline $1^{\text {st }} 30$ days & $12 \%$ & $20 \%$ \\
\hline $2^{\text {nd }} 30$ days & $8 \%$ & $15 \%$ \\
\hline Final 30 days & $4 \%$ & $10 \%$ \\
\hline
\end{tabular}




\section{Sampling of fish}

Fish sampling was done by catching all fishes of individual tanks at three days interval. Fishes were caught by using small triangle shaped push net (Fig. 3). The weighing process was done by an
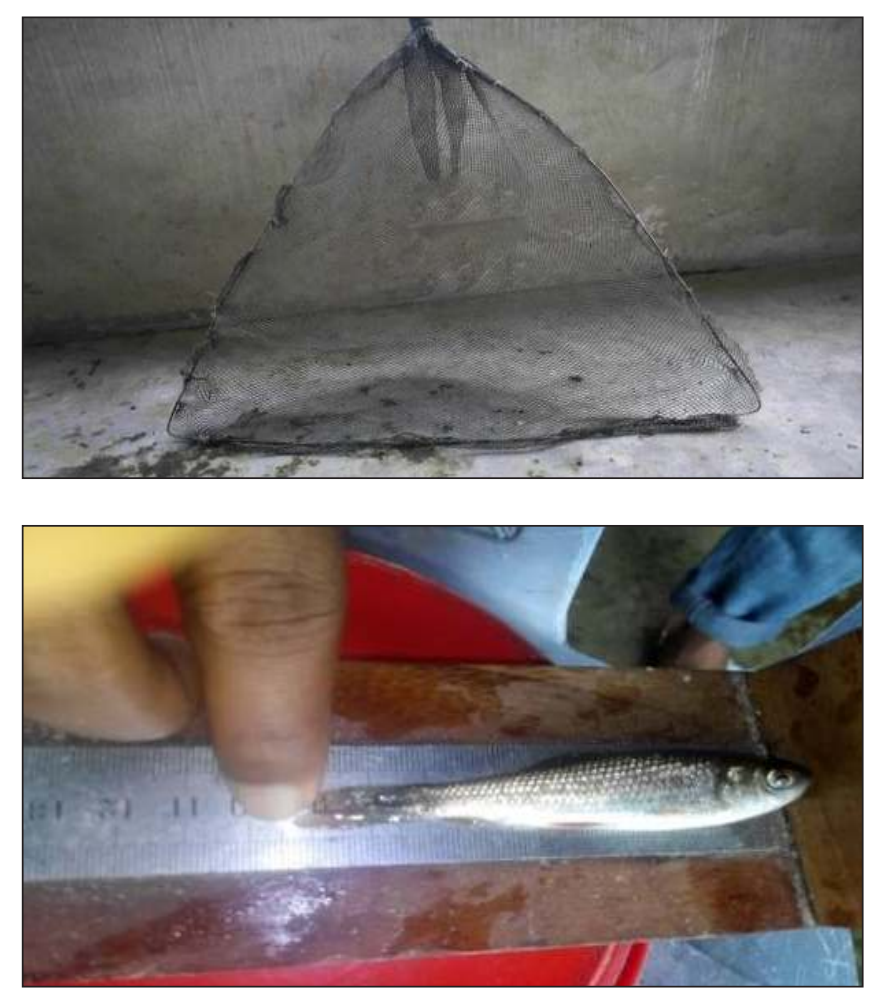

Fig. 3: Sampling and weighing of fish.

\section{Aeration installation}

Air stone aerators were applied to provide sufficient oxygen powered by electricity. A single air stone was allocated for each tank. The aerator motors were attached with the main structure of the roof of the shed. The aeration was operated for 24 hours during the experimental period.

\section{Study of growth parameters of fish}

For evaluating the growth of fish, different growth parameters such as length gain $(\mathrm{cm})$, weight gain (g), percent (\%) weight gain, specific growth rate (SGR \% per day) and production (kg/ha/100 days) were taken into consideration and were measured using the formula given below. The length and weight of fish were measured using centimeter scale and electric balance (Model; HKD-620ASLed) in grams.

$$
\begin{aligned}
\text { Weight gain }(\mathrm{g})= & \text { Mean final weight }(\mathrm{g})- \\
& \text { Mean initial weight }(\mathrm{g})
\end{aligned}
$$

electric balance (MODEL: HKD-620AS-LEDE) in gram. The length was recorded by measuring scale in cm (Fig. 3). Sampling was performed in the morning at around 9:00 am prior to delivering feed to observe growth and health conditions.
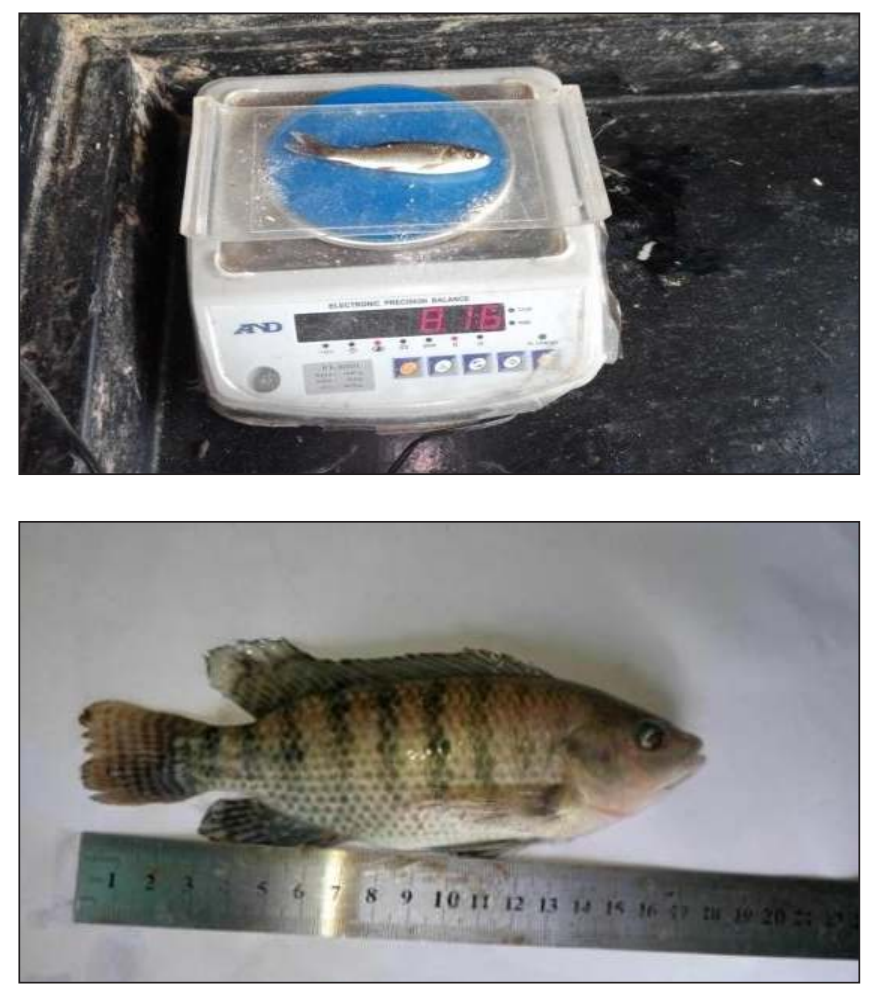

Percent (\%) weight gain $=\frac{\mathrm{A}-\mathrm{B}}{\mathrm{B}} \times 100$

Where, $\mathrm{A}=$ Mean final weight and $\mathrm{B}=$ Mean initial weight

Survival rate $=\frac{\text { No. of fish harvested }}{\text { No. of fish stocked }} \times 100$

Production $=$ No. of fishes harvested $\times$ Average final weight increase of fishes

\section{Study of water quality parameters}

During the experiment, water quality parameters of the experimental tanks were recorded very intensively two times daily. Water quality parameters especially temperature, $\mathrm{DO}, \mathrm{pH}$ were measured in the morning and afternoon daily and all the tests were performed in the experimental shed. Different physico-chemical parameters including DO was measured using digital DO meter (Model: CE 225908; Fig. 4) in mg/l. Water temperature was measured by using digital thermometer (model: $\mathrm{CE} 225908$ ) in ${ }^{\circ} \mathrm{C}$ and $\mathrm{pH}$ was recorded by digital $\mathrm{pH}$ meter (Model: CE 224469). 


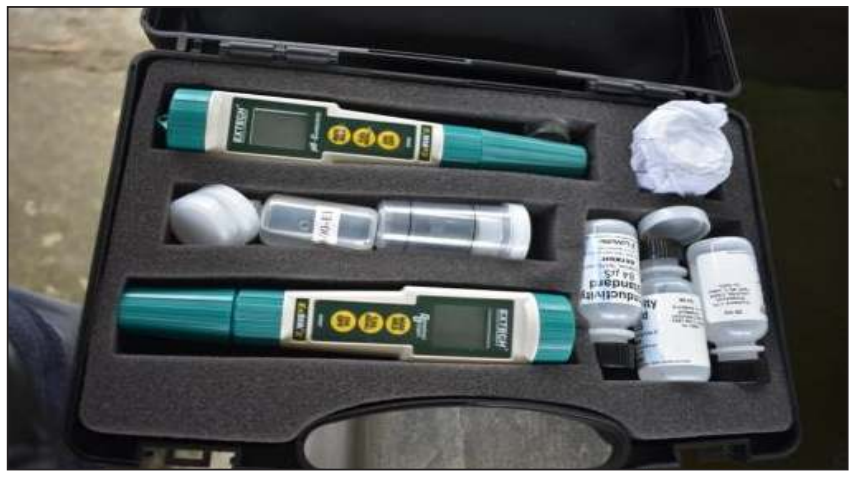

Fig. 4: Digital DO meter

\section{Data analysis}

Collected fish growth and water quality data were recorded in MS Excel 2010. Statistical analysis was done to evaluate the effect of the two treatments $\left(\mathrm{T}_{1}\right.$ and $\left.\mathrm{T}_{2}\right)$ on the growth of fish, whether significant or not. Independent sample TTest was performed to test the significance of difference among different water quality parameters. The entire statistical test was conducted by using SPSS (Statistical Package for Social science) version 16. The graph was prepared by using both MS Excel and SPSS.

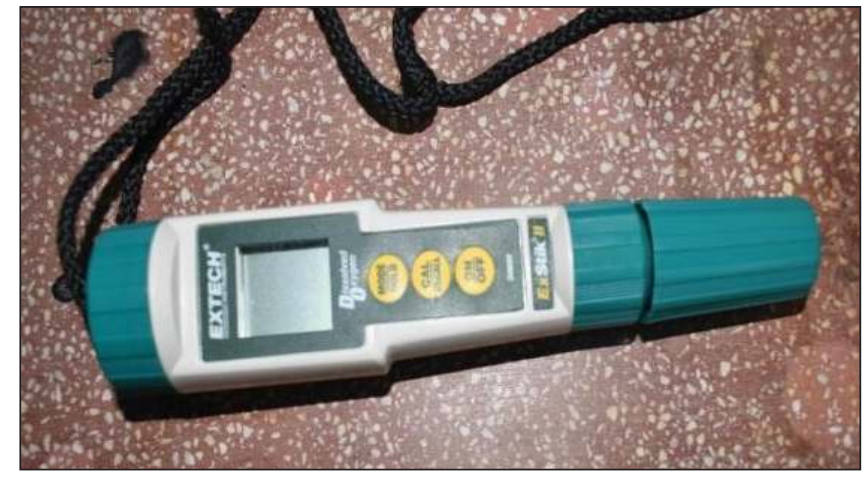

\section{RESULTS}

The authors obtained following results:

\section{Final weight}

The initial weight of individual was $7.52 \pm 1.81 \mathrm{~g}$ and $14.75 \pm 0.19 \mathrm{~g}$ for $\mathrm{T}_{1}$ and $\mathrm{T}_{2}$, respectively. The final mean weight of each fish was $44.01 \pm 5.65 \mathrm{~g}$ for $\mathrm{T}_{1}$ and $139.94 \pm 1.29 \mathrm{~g}$ for $\mathrm{T}_{2}$, respectively with no significant difference $(p<0.05)$ between the treatments.

Table 5: Weight gain performances (mean \pm SD) of individual tilapia in experimental tank.

\begin{tabular}{|l|c|c|}
\hline Growth parameters & $\mathbf{T}_{1}$ & $\mathbf{T}_{2}$ \\
\hline Initial weight $(\mathrm{g})$ & $7.52 \pm 1.81$ & $14.75 \pm 0.19$ \\
\hline Final weight $(\mathrm{g})$ & $44.01 \pm 4.03$ & $139.94 \pm 1.29$ \\
\hline Weight gain $(\mathrm{g})$ & $36.49 \pm 4.09$ & $125.19 \pm 1.29$ \\
\hline$\%$ Weight gain & $485.23 \pm 0.00$ & $1715.05 \pm 0.00$ \\
\hline
\end{tabular}

\section{Weight gain}

This controlled experiment was conducted to assess the growth of rohu and tilapia frequently in 3 days interval. In this study, the average weight gain of $\mathrm{T}_{1}$ was $36.49 \pm 4.09 \mathrm{~g}$ and for $\mathrm{T}_{2}$ was $125.19 \pm 1.29 \mathrm{~g}$, respectively. The difference in weight gain is notably remarkable between two treatments. The weight gain was found higher in $\mathrm{T}_{2}$ than $\mathrm{T}_{1}$ (Table 5). In term of weight gain, in the most sampling stages, the performance in $\mathrm{T}_{2}$ was significantly $(\mathrm{p}<0.05)$ higher than $\mathrm{T}_{1}$. In term of growth trend, after about a month, the different trends of weight gain were observed. The higher weight gain in $T_{2}$ was observed from the $5^{\text {th }}$ sampling. However, it was remarkable increment growth after about a month.

\section{Percent weight gain (\%)}

The mean percent weight gain was higher in $\mathrm{T}_{2}$ $(1715.05 \pm 0.00)$ than $\mathrm{T}_{1}(485.23 \pm 0.00)$. The higher percent weight (1715.05\%) was found in $\mathrm{T}_{2}$ where fishes were fed at the rate of $20 \%, 15 \%$, and $10 \%$ of the body weight in $1^{\text {st }}, 2^{\text {nd }}$ and $3^{\text {rd }}$ month with average individual weight of $14.75 \pm 0.19$ g (Fig. 5). 


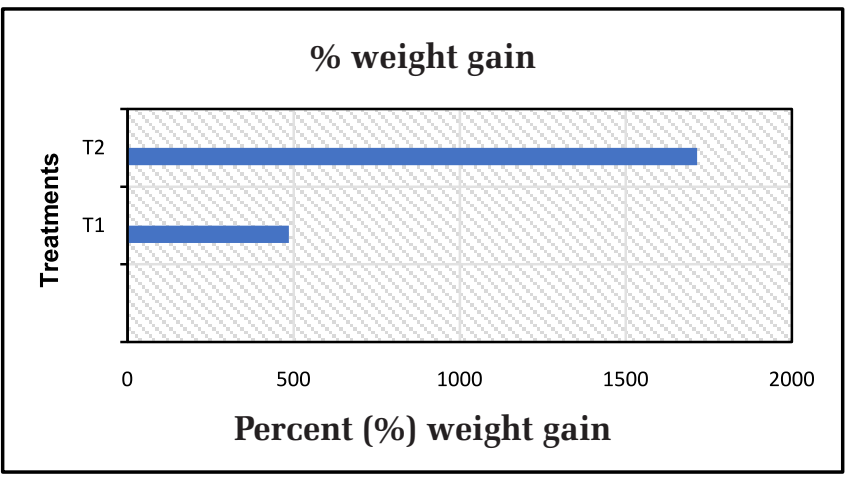

Fig. 5: Percent weight gain in two treatments.

\section{Feed conversion ratio (FCR)}

The feed conversion ratio was calculated by taking into consideration the total amount feed used in the experiment. Feed conversion ratio values of floating feed used for feeding the fish in $\mathrm{T}_{1}$ and $\mathrm{T}_{2}$, respectively were $2.86 \pm 0.14$ and $2.23 \pm 0.18$ (Fig. 6 ).

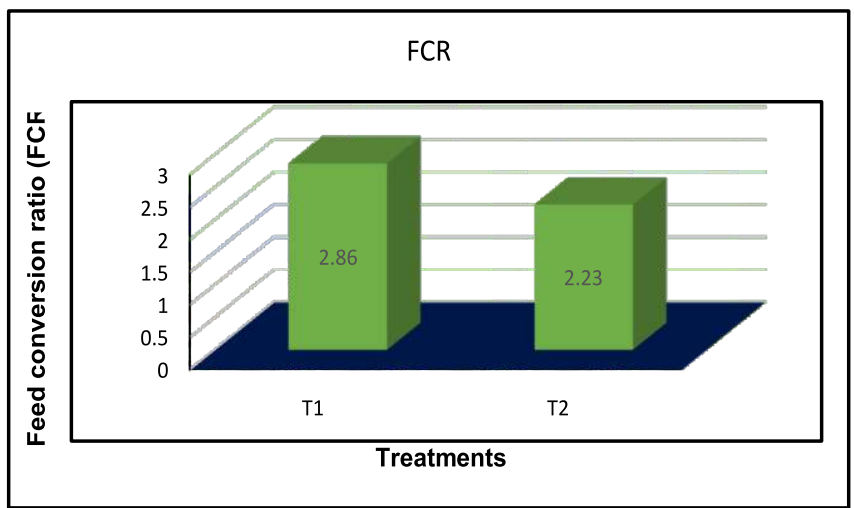

Fig. 6: Feed conversion ratio in sinking $\left(T_{1}\right)$ and floating $\left(T_{2}\right)$ feed.

\section{Total production $\left(\mathrm{g} / \mathrm{cm}^{3}\right)$}

The total productions at the end of the study were $278.19 \pm 0.00 \mathrm{~g}$ and $1119.52 \pm 0.00 \mathrm{~g}$ per cm3 in $\mathrm{T}_{1}$ and $\mathrm{T}_{2}$, respectively (Fig. 7). The production was higher in the tanks fed with $20 \%, 15 \%$, and $10 \%$ of the body weight.

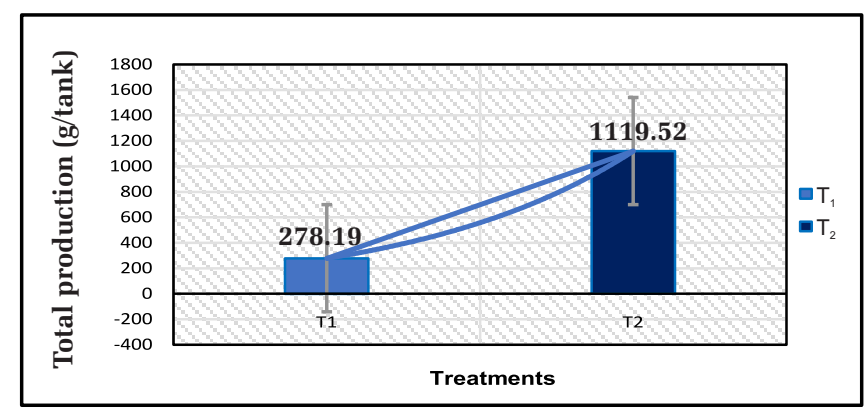

Fig. 7: Total production of tilapia in the two treatments $\left(\mathrm{T}_{1}\right.$ and $\left.\mathrm{T}_{2}\right)$.

\section{Water quality parameters}

The mean values of tested water quality parameters such as temperature and DO of the experimental ponds are presented in Table 6 . There was no significant difference $(p<0.05)$ in the temperature in morning and evening in both treatments. The difference of dissolved oxygen content was very low between two treatments. The dissolved oxygen contents in both treatments were similar because aerators were installed in all the tanks.

Table 6: Water temperature of experimental tanks.

\begin{tabular}{|l|c|c|c|}
\hline $\begin{array}{l}\text { Water quality } \\
\text { parameters }\end{array}$ & Treatments & Morning & Evening \\
\hline $\begin{array}{l}\text { Temperature } \\
\left(0^{\mathrm{C}}\right)\end{array}$ & $\mathrm{T}_{1}$ & $27.19 \pm 1.46$ & $28.23 \pm 1.58$ \\
\hline $\mathrm{DO}(\mathrm{mg} /)$ & $\mathrm{T}_{2}$ & $28.54 \pm 1.43$ & $28.65 \pm 1.67$ \\
& $\mathrm{~T}_{1}$ & $5.58 \pm 0.82$ & $6.15 \pm 0.65$ \\
& $\mathrm{~T}_{2}$ & $5.85 \pm 0.85$ & $6.58 \pm 0.82$ \\
\hline
\end{tabular}

\section{DISCUSSION}

In the present study, the fishes are fed with floating feed in treatment 1 and treatment 2 . The difference in weight gain was found between these two treatments. The mean initial weight of the rohu in the 3 tanks of $\mathrm{T}_{1}$ was $7.52 \pm 1.81$ and in the other 3 tanks of $\mathrm{T}_{2}$ was $14.75 \pm 0.19$. At the end of the experiment, the mean final weight of the fish in $\mathrm{T}_{1}$ was $44.01 .77 \pm 4.03$ and $139.94 \pm 1.29$ in $\mathrm{T}_{2}$. The mean weight gain was $36.49 \pm 4.09$ and 125.19 \pm 1.29 in $T_{1}$ and $T_{2}$, respectively. The weight gain was higher in $\mathrm{T}_{2}$ which might be due to the fact that fish had taken more amount of feed in almost similar level of water quality.

To evaluate the utilization of feed, feed conversion ratio (FCR) was calculated that was given to the fish as feed supplement. The expected FCR for tilapia ranges from 1.5 to 2.0 (Watanabe et al., 2002). The FCRs of tilapia in present study were $2.86 \pm 0.14$ and $2.23 \pm 0.18$ in $\mathrm{T}_{1}$ and $\mathrm{T}_{2}$, respectively. The FCR in $\mathrm{T}_{1}$ was within expected range but in case of $\mathrm{T}_{2}$, it was higher than the accepted value. Feed conversion ratio (FCR) of $\mathrm{T}_{2}$ was higher than expected level as the total amount of delivered feed was taken into consideration during calculating the FCR. 
The survivability of rohu and tilapia in the present study was $100 \%$. Hussain et al. (1987) recorded survival rate of tilapia ranged from 82 to $90 \%$. In this study, the highest survivability might be the cumulative result of good water quality parameters due to weekly water exchange; quality feed uses and proper maintenance during culture. This result of $100 \%$ survival in both the treatments confirms that indoor tank-based aquaculture systems can be developed in Bangladesh where land is getting scarce as a natural resource.

Battes et al. (1979) reported that water temperature plays a vital role in regulating the metabolic process of fish. Therefore, it is very important to maintain the temperature of the culture unit. The suitable range of tilapia culture is 26 to $32^{\circ} \mathrm{C}$ (Khan et al., 2008). The body temperature of fish is related to water temperature, and growth, reproduction and other biological activities are influenced by the temperature largely. The water temperature of the experimental tanks was within the suitable range of tilapia culture. The average value of temperature in $\mathrm{T}_{1}$ was $27.19 \pm 1.46$ and $28.23 \pm 1.58$ during morning and evening, respectively. In $\mathrm{T}_{2}$, the mean temperature was $28.54 \pm 1.43$ and $28.65 \pm 1.67$ in morning and evening, respectively.

Balarin and Hatton (1979) reported that tilapia can tolerate dissolved oxygen concentration as low as $0.1 \mathrm{mg} / \mathrm{l}$. Higher level of DO concentration was recorded in the experimental tanks as a result of aerator installation. In the present study, the mean average oxygen content of $T_{1}$ was $5.58 \pm 0.82$ and $6.15 \pm 0.65$ during morning and evening, respectively. In $\mathrm{T}_{2}$, the mean dissolved oxygen content was $5.85 \pm 0.85$ and $6.58 \pm 0.82$ in morning and evening, respectively. Tilapia can survive at very low dissolved oxygen content.

\section{CONCLUSION}

This study suggests that tank-based aquaculture can be developed in the indoor system that can ensure almost $100 \%$ survivals. This study also had an introspective observation to detect consecutive growth performance and yield in relation to FCR. This study reveals an outstanding clarification on the growth performance of fish in different sampling stages in relation to supplied feed at various stages of fish growth and thus the wastage of feed at the final stages of the culture period can be limited due to the proper demonstration of feed to reduce the FCR. From the experiment, it is possible to produce a higher number of fish in such an improved way from a small parcel of land.

However, further study is needed to explore the relative cost-effectiveness of the culture of rohu and tilapia fish in higher stocking density in tankbased aquaculture system. For producing high number of fish, it is important to maintain water quality parameters and selection of right quality feed for feeding the fish. This study also indicates that farmers in Bangladesh practicing inefficient feeding systems wasting high-cost floating feed due to lack of proper knowledge on growth and production at different stages. This study reveals an outstanding clarification and will assist the researchers and academicians who want to culture rohu and tilapia in intensive aquaculture system by using floating feed and contribute to modify the research in near future.

\section{CONFLICT OF INTEREST}

There is no conflict of interest regarding the submitted manuscript.

\section{REFERENCES}

1. Abid M. and Ahmed M.S. (2009). Growth response of Labeo rohita fingerlings fed with different feeding regimes under intensive rearing. Journal of Animal \& Plant Sciences. 19(1): 45-49.

2. Ashok K. V. (2020). Conservation Status of Amniotes found in and around Balapur Pond of District Prayagraj (Uttar Pradesh), India. International Journal of Biological Research. 8 (1): 01-05. 10.14419/ijbr.v8i1.30854

3. Ashok K. V. (2021). Ichthyo-faunal diversity of Alwara Lake: Threats and Conservation Status. International Journal of Zoological Investigation. $7(2)$ : 479-485. https://doi.org/ 10.33745/ijzi.2021.v07i02.023. 
4. Balarin J.D. and Hatton J.P. (1979). Tilapia: A guide to Their Biology and Culture in Africa. Unit of Aquatic Pathology, University of Stirling, Scotland. 174p.

5. Battes K., Constania L., Valencive N., Lordache L. and Tarus T. (1979). Carp culture in floating cages. Bulletin of Correct Piscis. 1(1-2): 68-95.

6. Chakraborty B. K. (2020). Rearing and Nursing of Thai Pangas, Pangasianodon hypophthalmus (Sauvage, 1978) with different feeds. International Journal of Biological Innovations. 2 (2):277-286. https://doi.org/10.46505/IJBI.2020.2224

7. Chakraborty B. K. (2021). Induction of spawning and nursing pangas, Pangasiano don hypophthalmus (Sauvage, 1878) under hatchery system. International Journal of Biological Innovations. 3 (2): 264-270. https://doi.org/10.46505/IJBI.2021.3203

8. DoF (2020). National Fish Week Compilation, Department of Fisheries, Ministry of Fisheries and Livestock, Dhaka, Bangladesh. 144-145p.

9. FAO (2000). The State of World Fisheries and Aquaculture. Food and Agriculture Organization of the United Nations, Rome, Italy.

10. Hussain M.G., Rahman M.A. and Akhteruzzaman M. (1987). A study on the production of $O$. niloticus (Linnaeus) under intensive system in Bangladesh. Bangladesh J. Fish Res. 1(2): 19-23.

11. Islam M. S., Kohinoor A. H. M., Bhadra A., Islam M. S. and Masum M. (2020). Existing Cropping Pattern and Adoption of New Farming Technology in the Plain Land Ecosystem of Phulpur Upazila of Mymensingh. International Journal of Biological Innovations. 2 (2): 129-136. https://doi.org/10.46505/IJBI.2020.2208.
12. Kumar A., Bajpeyee A. K. and Yadav C.B. (2020). Effects of Dietary vitamin-C on Biochemical and Morphometric parameters of Labeo rohita. International Journal of Biological Innovations. 2 (2): 174-177. https://doi.org/10.46505/IJBI.2020.2214

13. Lugert V., Thaller G., Tetens G., Schulz C. and Krieter J. (2016). A review on fish growth calculation: multiple functions in fish production and their specific application. Reviews in Aquaculture. 8 (1): 30-42. https://doi.org/10.1111/raq.12071.

14. Khan S., Hossain M.S. and Hossain M.M. (2008). Production and economics of GIFT strain of tilapia (Oreochromis niloticus) in small seasonal ponds. Progressive Agriculture. 19(1): 97-104.

15. Romano N. and Ng Wing-Keong (2013). A review of the nutrition and feeding management of farmed tilapia throughout the culture cycle. Reviews in Aquaculture. 5(4): 220-254. https://doi.org/10.1111/raq.12014

16. Shaheen T., Ayub M., Hayat S., Abidi S.Z.A. and Tahir S. (2000). Impact of different levels on the survival and growth of Labeo rohita at constant level of protein. Pakistan Journal of Fisheries. 1(1): 95-102.

17. Stickney R.R.J.H., Geachin R.B. and Isbell W.A. (1979). Growth of tilapia (Oreochromis niloticus) in ponds with different organic fertilizations. Aqua. 19: 189-194.

18. Watanabe W.O., Losordo T.M., Fitzsimmons K. and Hanley F. (2002). Tilapia production systems in the Americas: Technical Advances, Trends and Challenges. Reviews in Fisheries Science. 10(3-4): 465-498. 10.1080/20026491051758 